\title{
Removal of lead(II), copper(II), cobalt(II) and nickel(II) ions from aqueous solutions using carbon gels
}

\author{
Małgorzata Osińska ${ }^{1}$
}

Received: 18 August 2016 / Accepted: 4 November 2016 / Published online: 14 November 2016

(C) The Author(s) 2016; This article is published with open access at Springerlink.com

\begin{abstract}
The carbon gel and carbon gel doped with $0.5,1$ and $2 \mathrm{wt} \%$ of graphite intercalation compound were used for the removal of heavy metals from aqueous solutions. These materials were prepared by a sol-gel process that involves a polycondensation of resorcinol and formaldehyde. Nitrogen adsorption, scanning electron microscopy, energy dispersive spectroscopy and fourier transform infrared spectroscopy were used for a morpho-structural adsorbent investigation. In the present paper, $\mathrm{Cu}, \mathrm{Co}, \mathrm{Pb}$ and $\mathrm{Ni}$ ions adsorption experiments were carried out in batch conditions under magnetic stirring. The effect of some parameters such as contact time, metal ions' concentration and $\mathrm{pH}$ were examined. Adsorption data on all sorbents, followed both the Frendlich and Langmuir models. The data better fitted the Langmuir isotherm than the Frendlich one. The highest degree of removal was achieved for $\mathrm{Pb}$ ions at the initial concentration of $10 \mathrm{mg} / 1$ and for $2 \mathrm{~g} / \mathrm{l}$ adsorbent dose. Adsorption results expressed as adsorption capacities showed that carbon gel doped with $2 \mathrm{wt} \%$ of graphite intercalation compound is the best adsorbent.
\end{abstract}

Electronic supplementary material The online version of this article (doi:10.1007/s10971-016-4256-0) contains supplementary material, which is available to authorized users.

Małgorzata Osińska

malgorzata.osinska@put.poznan.pl

1 Faculty of Chemical Technology, Institute of Chemistry and Technical Electrochemistry, Poznań University of Technology, ul. Berdychowo 4, Poznań 60-965, Poland
Graphical Abstract

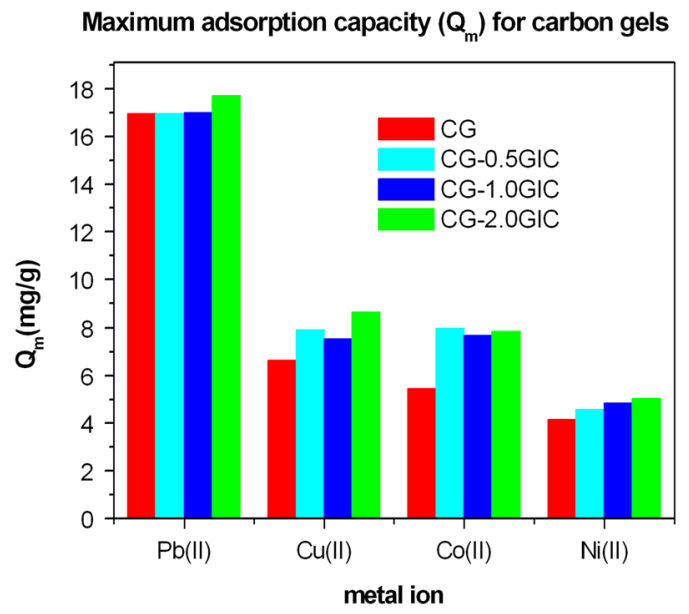

Keywords Carbon gels $\cdot \mathrm{Pb}$ (II) $\cdot \mathrm{Cu}$ (II) $\cdot \mathrm{Co}$ (II) and $\mathrm{Ni}(\mathrm{II})$ ions $\cdot$ Adsorption of heavy metal ions $\cdot$ Graphite intercalation compound

\section{Introduction}

The development of industrial activities is causing an increasing amount of wastewater. Among the many contaminants found in wastewater, particular attention should be paid to heavy metals. The presence of heavy metals results in negative effects on human life and the environment due to their high toxicity. The increased awareness and concern about the natural world as well as strict legislation have contributed to more efforts in research within the area of finding efficient techniques for removing these contaminants from wastewater. 
The adsorption process is regarded as one of the most effective techniques because of its simplicity and high efficiency [1].

Excellent sorbents are carbon gels due to their high surface area. Carbon gels are mainly prepared through polycondensation of resorcinol with formaldehyde and sodium carbonate added as a catalyst [2-4]. Such obtained organic gels are dried and then subjected to carbonisation in an inert atmosphere. There are three main methods of drying organic gels: drying with supercritical $\mathrm{CO}_{2}[5,6]$ creating gels named aerogels, drying at ambient temperature [7-10], which gives xerogels or by freeze drying [11]cyrogels. During carbonisation, organic gels are heated from room temperature to the required pyrolysis temperature, generally $600-1050^{\circ} \mathrm{C}[12-15]$.

Despite the unique properties of carbon gels, there are still only a few reports about their application in the adsorption of heavy metals. This can be attributed to the high synthesis cost of these materials. One of the works on the adsorption of heavy metals on carbon gels is the research of Meena et al. [16]. They studied the removal of $\mathrm{Cd}(\mathrm{II}), \mathrm{Pb}$ (II), $\mathrm{Hg}$ (II), $\mathrm{Cu}$ (II), $\mathrm{Ni}$ (II), $\mathrm{Mn}$ (II) and $\mathrm{Zn}$ (II) from aqueous solutions using commercially supplied aerogel. This gel showed nearly $100 \%$ adsorption of metal ions under optimised conditions. The research of Goel et al. [17] and Kadirvelu et al. [18] confirmed the high efficiency of aerogels in the removal of $\mathrm{Pb}(\mathrm{II}), \mathrm{Hg}$ (II), $\mathrm{Ni}$ (II) and $\mathrm{Cd}(\mathrm{II})$. Kadirvelu additionally checked their adsorption capacities in a multi-component solution. Girgis and coworkers [19] demonstrated that the adsorption capacity of carbon xerogels in relation to $\mathrm{Cu}$ (II) ions from aqueous solutions, is controlled by the specific surface area and surface chemical nature (acidic O-functional groups).

Yang and coworkers [1] found that the removal efficiencies of $\mathrm{Pb}, \mathrm{Zn}$ and $\mathrm{Cu}$ by $\mathrm{N}$-doped carbon xerogels were about 1.6-2 times higher then those by carbon xerogels. This excellent adsorption performance of $\mathrm{N}$-doped xerogels is mainly dependent on the surface $\mathrm{N}$ functional groups rather than the textural properties.

A number of studies devoted to expanded graphite (EG) also confirmed its sorption properties [20-27]. EG can be obtained by the process of exfoliation of graphite intercalation compounds (GICs), which can be prepared by the introduction of certain molecules called intercalates, between the interlayer spacing of graphite. During the process of exfoliation, intercalates are released from the graphite flakes. These effects are responsible for a huge expansion of EG along the c-axis as well as a tremendous increase in specific surface area.

In the present work, I synthesised and examined for the first time carbon-GIC composites during the processes of adsorption of heavy metals. The aim of this work was to prepare carbon-GIC composites by the addition of
$\mathrm{NiCl}_{2}-\mathrm{FeCl}_{3}$-GIC to carbon gels. I expected that this component would be involved in the development of the porous structure of the carbon gels. And also because Moreno [12] concluded that the carbonisation temperature has a significant effect on the textural properties of the carbon xerogels and that an increase in the carbonisation temperature causes a decrease in porosity; my xerogels were pyrolysed at the relatively low temperature of $750{ }^{\circ} \mathrm{C}$.

\section{Experimental}

\subsection{Chemicals}

All chemicals were obtained commercially and were used without further purification: resorcinol ( $\mathrm{POCH}$, Poland), formaldehyde (37 wt.\%, stabilised $10 \mathrm{wt} . \%$ methanol, Merck, Germany), sodium carbonate (POCH, Poland), acetone (POCH, Poland), N-cetyl-N,N,N-trimethylammoniumbromide (CTAB) (Merck, Germany), nickel(II) chloride anhydrous (Merck, Germany), ferric(III) chloride anhydrous (Merck, Germany), purified flaky graphite (99.98 wt.\% C, flakes $100-125 \mu \mathrm{m}$ in diameter), sodium hydroxide (POCH, Poland), potassium hydroxide (POCH, Poland), nitric acid (POCH, Poland), hydrochloric acid (POCH, Poland). Analytical grade reagents were used for preparation of metal solutions: copper(II) sulphate, nickel(II) nitrate, cobalt(II) nitrate and lead(II) nitrate (all POCH, Poland). Distilled water was used for preparing all the solutions.

\section{$2.2 \mathrm{NiCl}_{2}-\mathrm{FeCl}_{3}$-GIC synthesis}

$\mathrm{NiCl}_{2}-\mathrm{FeCl}_{3}$-GIC was prepared using the molten salts method. Purified flaky graphite $(99.98$ wt.\% C, flakes $100-125 \mu \mathrm{m}$ in diameter) and anhydrous chlorides of $\mathrm{Ni}$ and Fe were used as reactants. The molar ratio of graphite to metal salts was chosen to be 3:1 and the molar ratio of $\mathrm{NiCl}_{2}: \mathrm{FeCl}_{3}$ was $4: 1$. Before intercalation the glass reactor loaded with the mixture of graphite and metal salts was purged with a nitrogen flow. The aim of this procedure was to remove moisture and air. The reactor was sealed at both ends, also under continuous nitrogen flow and was then inserted into a computer controlled furnace. The process of intercalation was carried out at $450{ }^{\circ} \mathrm{C}$ for $72 \mathrm{~h}$. To remove unreacted salts, the reaction product was filtered and washed out with a large amount of diluted $\mathrm{HCl}$ solution. Then the sample was rinsed with water and acetone. After such preparation, the product was stored in a moisture free atmosphere for drying at ambient temperature. 


\subsection{Carbon xerogel and carbon-GIC composites preparation}

RF hydrogels were synthesised by the polycondensation of resorcinol $(\mathrm{R})$ with formaldehyde $(\mathrm{F})$ with sodium carbonate (C) as a catalyst and surfactant (S) CTAB. Molar ratios R/F, $\mathrm{R} / \mathrm{C}$ and R/S were $0.5,1000$ and 125, respectively. Resorcinol was mixed with the catalyst, surfactant and deionised water to dissolve by stirring them for not less than $1 \mathrm{~h}$. After the dissolution, formaldehyde was added and stirred for 24 h. The $\mathrm{pH}$ value of the mixture was adjusted to equal 6.0 by the addition of $1 \mathrm{M} \mathrm{NaOH}$ solution. The mass percentage of the reactants in water solution was set at $40 \%$.

In order to obtain carbon-GIC composites, the mass of GIC in the solution was adjusted so its content in carbon formed after the carbonisation of the mixture of resorcinol and formaldehyde was $0.5,1$ and $2 \%$ by weight. The mass percentage of RF and GIC in solution was set at $40 \%$. In this case, the resorcinol was mixed with the catalyst and water. After the dissolution, formaldehyde was added and stirred for $24 \mathrm{~h}$. The surfactant dissolved in water was mixed with GIC for $80 \mathrm{~min}$, , after which the solution was added to the mixture of RF. Then the $\mathrm{pH}$ was adjusted, by the addition of $1 \mathrm{M} \mathrm{NaOH}$, to a value of 6 and the mixture was stirred for another hour.

These solutions were poured into polypropylene vessels that were sealed. Then organic gel solutions were allowed to gelate at $50{ }^{\circ} \mathrm{C}$ for $96 \mathrm{~h}$. After this time, the RF and RF-GIC gels were removed from the drying stove and cooled at room temperature.

All the samples underwent the operation of water removal through the exchange with acetone according to a method already applied elsewhere [28].

Subsequently, the dried samples of gels were carbonised in a tube furnace under nitrogen flow at $750{ }^{\circ} \mathrm{C}$ for $3 \mathrm{~h}$ using a heating rate of $10^{\circ} \mathrm{C} / \mathrm{min}$, then the heating was turned off and the tube furnace was cooled to $50^{\circ} \mathrm{C}$.

The products obtained in this work were labelled as follows:

$\mathrm{CG}$-carbon gel (without GIC),

CG-0.5GIC - carbon gel doped with $0.5 \mathrm{wt} \%$ of GIC,

CG-1.0GIC - carbon gel doped with $1.0 \mathrm{wt} \%$ of GIC,

CG-2.0GIC—carbon gel doped with $2.0 \mathrm{wt} \%$ of GIC.

\subsection{Adsorbents characterisation}

A scanning electron microscopy (SEM) (Hitachi S-3400N) coupled with the energy dispersive spectrometer (EDS) (Thermo Electron Corp., model No. 4481B-1UES-SN with the NSS Spectral Imaging System software) was used for observing the morphology on the adsorbent surface as well as determining semi-quantitatively their chemical composition.

The BET-specific surface areas $\left(S_{\mathrm{BET}}\right)$ of samples were determined from the isotherms measured by $\mathrm{N}_{2}$ adsorption at $-195.5^{\circ} \mathrm{C}$ using a relative pressure ranging from 0.06 to 0.30 (Autosorb iQ-Quantachrome). The cumulative pore volume between 1.7 and $300 \mathrm{~nm}$ and mesopore size distributions were determined from the desorption branch of the $\mathrm{N}_{2}$ isotherm using the Barret-Joyner-Halenda method.

The surface functional groups were qualitatively determined by FTIR spectra of carbon xerogels, recorded in the wavenamber range of $4000-400 \mathrm{~cm}^{-1}$. FTIR measurements were carried out with BRUKER-model 113V IR spectrometer using the $\mathrm{KBr}$ technique.

The contents of surface oxygen functional groups were determined according to the Boehm method [29].

The $\mathrm{pH}$ of carbon gels was measured using the following procedure [30]: a portion of $0.4 \mathrm{~g}$ of the dry sample of adsorbent was added to $20 \mathrm{~cm}^{3}$ of distilled water and the suspension was stirred for $12 \mathrm{~h}$ to reach equilibrium. Then the $\mathrm{pH}$ suspension was measured.

\subsection{Adsorption of metal ions from aqueous solutions}

Four metal ions were studied: $\mathrm{Cu}(\mathrm{II}), \mathrm{Ni}(\mathrm{II}), \mathrm{Pb}$ (II) and $\mathrm{Co}$ (II). Adsorbate solutions, $1000 \mathrm{mg} / \mathrm{l}$, were prepared by dissolving suitable metal salts in acidified (with $\mathrm{HNO}_{3}$ ) distilled water to prevent formation of metal ions by hydrolysis. The solutions were diluted with distilled water to obtain the desired concentration of metal ions. An atomic absorption spectrometer (AAS 1N, Carl Zeiss-Jena, Germany) operating with an air acetylene flame was used for determining metal ions concentration at their respective wavelength. Three standard solutions with concentrations of metal ions in the linear range of the instrument were used to construct each calibration curve. All measurements were repeated three times.

Batch mode adsorption studies of $\mathrm{Cu}(\mathrm{II}), \mathrm{Ni}(\mathrm{II}), \mathrm{Pb}(\mathrm{II})$ and $\mathrm{Co}$ (II) were carried out at $25^{\circ} \mathrm{C}$ using $200 \mathrm{ml}$ of metal ion solutions with concentrations ranging between $10-50 \mathrm{mg} / \mathrm{l}$ and $400 \mathrm{mg}$ of adsorbent. These were agitated in a shaker for a known period of time (3-1440 min) and after each agitation period, the suspension of the adsorbent was separated from the solution by filtration using Whatman No. 1 filter paper. The effect of several parameters, such as $\mathrm{pH}$, metal ion concentrations and contact time on the adsorption was studied. The $\mathrm{pH}$ of the adsorptive solutions was adjusted using nitric acid or sodium hydroxide. Adsorption of metal ions on the walls of glass flasks, determined by running the blank experiments, was negligible. 
The percent of heavy metal removal $\left(R_{\mathrm{M}}\right)$ was calculated using Eq. (1):

$R_{\mathrm{M}}(\%)=\frac{\left(\mathrm{C}_{\mathrm{i}}-C_{\mathrm{e}}\right)}{C_{\mathrm{i}}} \cdot 100$

where: $C_{\mathrm{i}}$ and $C_{\mathrm{e}}$ are the initial and final metal ion concentrations $(\mathrm{mg} / \mathrm{l})$, respectively.

Adsorption capacities $\left(q_{\mathrm{e}}\right)$ (mg of metal per $\mathrm{g}$ of carbon gel) for each sorption system were determined using Eq. (2):

$q_{e}\left(\frac{m g}{g}\right)=\frac{V\left(C_{\mathrm{i}}-C_{e}\right)}{m}$

where: $V$ is the solution volume $(\mathrm{ml})$ and $m$ is the adsorbent mass (mg).

\section{Results and discussion}

\subsection{Physicochemical characteristics}

The SEM images of carbon gel CG and CG-GIC composites are shown in Figs. 1-4. These images allow the observation of the changes in morphology of carbon gels caused by the addition of $\mathrm{NiCl}_{2}-\mathrm{FeCl}_{3}-\mathrm{GIC}$ to the $\mathrm{RF}$ solutions. It was noted that $\mathrm{CG}$ gel obtained after the carbonization of hydrogel free of GIC had a more compact structure than CG-GIC composites. CG-GIC composites were received in the form of easily crumbling lumps.

From the comparison of the SEM images shown in Fig. 1 with those presented in Figs. 2-4, the influence of $\mathrm{NiCl}_{2}-\mathrm{FeCl}_{3}-\mathrm{GIC}$ added to $\mathrm{RF}$ gel can be evaluated. The carbon material of sample $\mathrm{CG}$ is composed of particles in a wide range of dimensions and shapes. The mechanism of the polymerisation process was changed by the presence of $\mathrm{NiCl}_{2}-\mathrm{FeCl}_{3}-\mathrm{GIC}$ in the RF solution. These changes are visible especially in the shape, diameter and morphology of particles. For sample CG the irregularly shaped particles changed into spherical ones, showing the catalytic effect of the GIC addition to create CG-GIC composites. Based on the results of the EDS analysis (Table 1), one can notice an increase in oxygen content for the composites.

The porous structures of obtained carbon gels were characterised using the $\mathrm{N}_{2}$ adsorption-desorption isotherms (Table 2). The specific surface area for sample $\mathrm{CG}$ amounted to $444 \mathrm{~m}^{2} \mathrm{~g}^{-1}$. The BET surface area for composites CG-GIC became from about 5 to $23 \%$ higher as compared to that of carbon gel CG. On considering the structural data presented in Table 2, it is also clear that the addition of GIC led to the increase in the average pore diameter of mesopores and is responsible for the increase in their cumulative volume of pores.
Fig. 1 SEM images of carbon gel CG a,b

Fig. 2 SEM images of composite CG-0.5GIC a,b
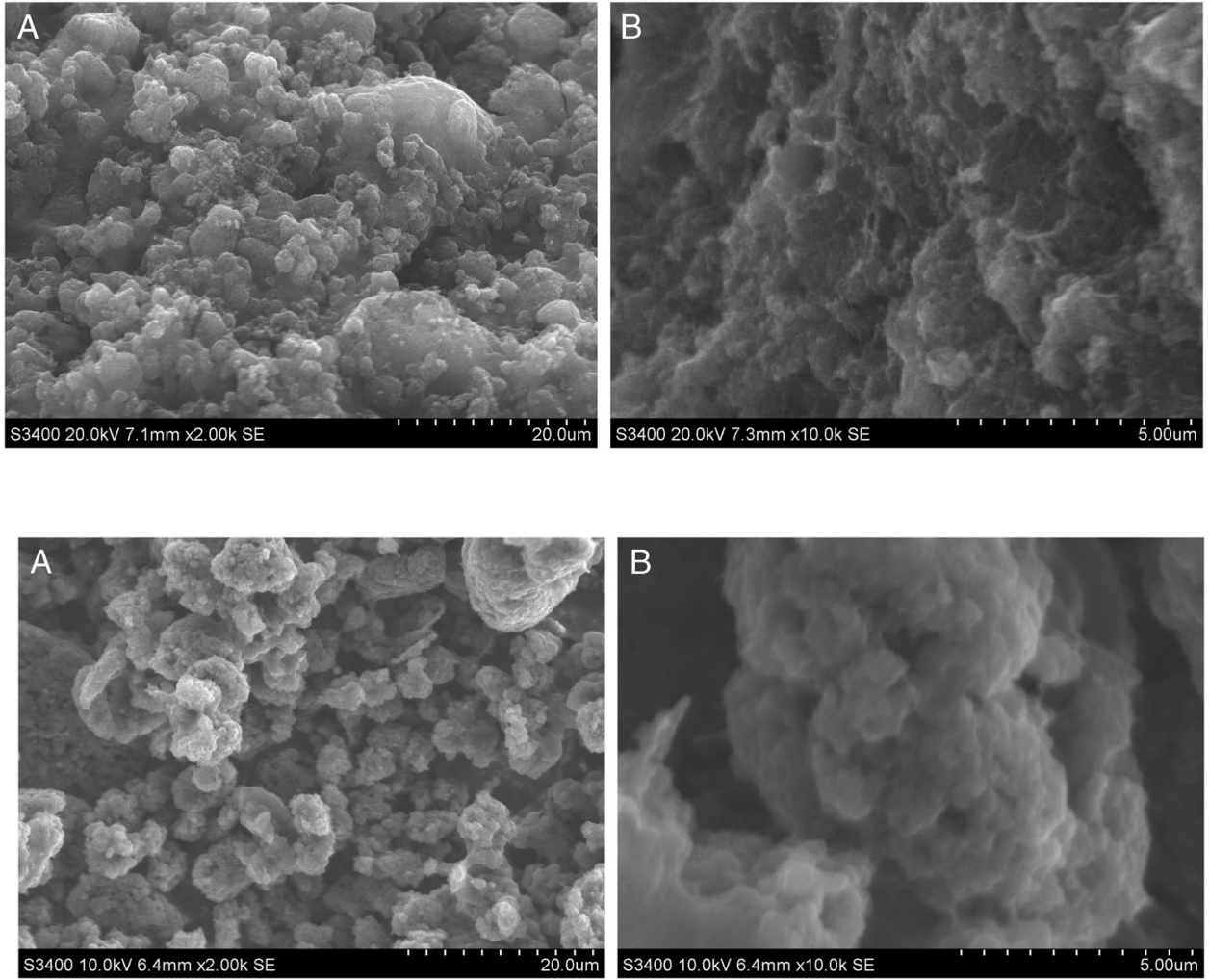
Fig. 3 SEM images of composite CG-1.0GIC a,b
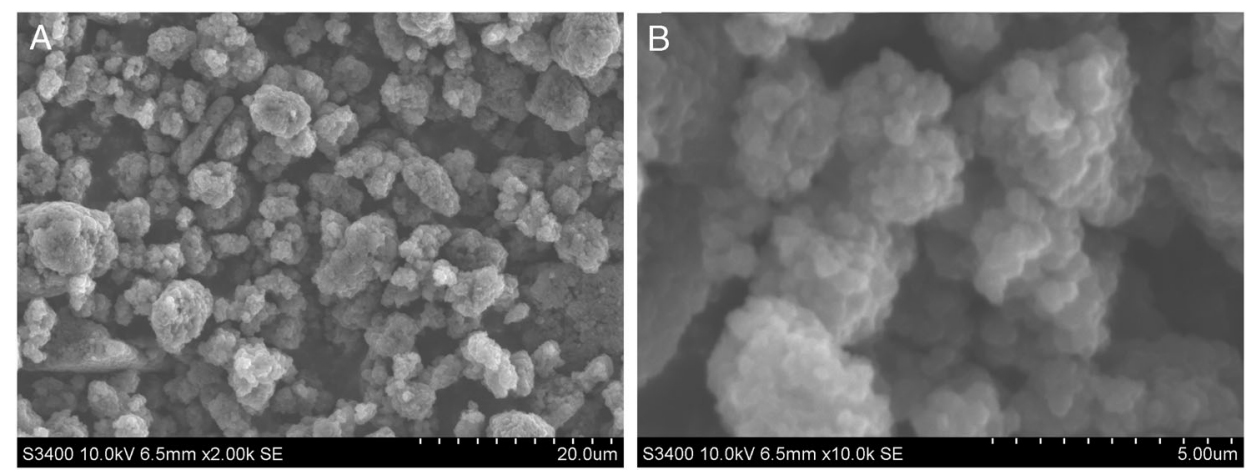

Fig. 4 SEM images of composite CG-2.0GIC a,b
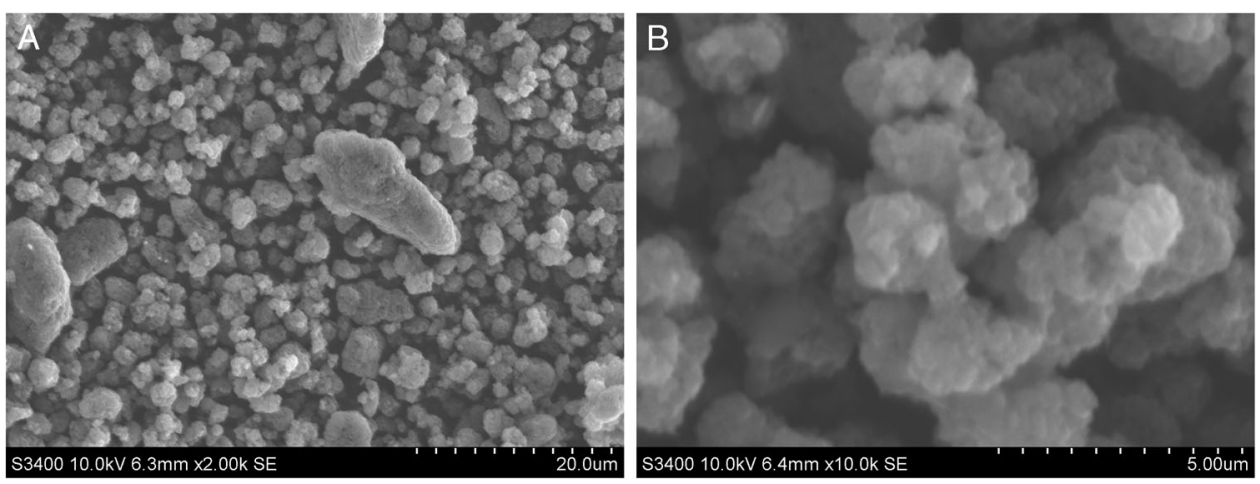

Table 1 Semi-quantitative EDS data for samples CG and CG-GIC

\begin{tabular}{lcccc}
\hline Element & \multicolumn{4}{l}{ Composition (at. \%) } \\
\cline { 2 - 5 } & CG & CG-0.5GIC & CG-1.0GIC & CG-2.0GIC \\
\hline $\mathrm{C}$ & 96.13 & 94.91 & 94.50 & 92.80 \\
$\mathrm{O}$ & 3.87 & 5.05 & 5.5 & 7.20 \\
$\mathrm{Ni}$ & - & n.d. & n.d. & n.d. \\
$\mathrm{Fe}$ & - & n.d. & n.d. & n.d. \\
\hline
\end{tabular}

n.d. not detected

Figure 5 depicts the FTIR spectra of the investigated samples. In all the spectra, a strong absorption band of $\mathrm{O}-\mathrm{H}$ stretching vibrations, observed in the region $3435-3440 \mathrm{~cm}^{-1}$, is associated with the surface hydroxylic groups and chemisorbed water [31-38]. The intensities of these peaks are similar for all samples. All spectra show a pronounced band at $1559-1578 \mathrm{~cm}^{-1}$. The complicated nature of the adsorption bands in this region suggests that aromatic ring bands and double bond $(\mathrm{C}=\mathrm{C})$ vibrations overlap $\mathrm{C}=\mathrm{O}$ stretching vibration bands and $\mathrm{OH}$ binding vibration bands $[32,33]$. In this region, the peak observed for sample CG-2.0GIC is about two times more intensive than for other samples.

The peaks corresponding to $\mathrm{C}-\mathrm{O}$ vibrations derived from the phenolic structure are visible in the region $1114-1159 \mathrm{~cm}^{-1}$ $[34,35]$. This peak is the most intense for sample CG-2.0GIC, lower for gels doped with 1 and $0.5 \%$ GIC and the lowest for gel CG.

The band appearing in the region $2921 \mathrm{~cm}^{-1}$ is connected with stretching vibrations between carbon and hydrogen, characteristic of $-\mathrm{CH}_{2-}$ and $-\mathrm{CH}_{3}$ structures $[36,37]$. The presence of this band suggests the existence of some aliphatic species on the surface of the carbon gel. The band noted in the region $2921 \mathrm{~cm}^{-1}$ is visible only for carbon gel free of GIC (sample CG).

Other bands of small intensities about and below $800 \mathrm{~cm}^{-1}$ can be ascribed to out-of plane vibration of $\mathrm{C}-\mathrm{H}$ moieties of aromatic structure [33, 39] are observed for GIC-doped samples.

As follows from the data presented in Table 3 , the carbon materials differ in the number of acid and basic functional groups and in the $\mathrm{pH}$. The addition of GIC leads to the changes in the $\mathrm{pH}$, for composites the $\mathrm{pH}$ was slightly higher than for carbon gel. The higher $\mathrm{pH}$ for composites is related to the presence of considerable amounts of acidic but also basic oxygen functional groups. Total content of surface oxide groups for composites with 1 and $2 \%$ addition of GIC is about two times higher than for sample CG. The importance of the effect of acid functional groups on the adsorption capacity for heavy metal ions has been reported by many researchers [40-43]. 
Table 2 Surface properties of carbon gel and GIC containing carbon gels

\begin{tabular}{llll}
\hline Sample & $\begin{array}{l}S_{\text {BET }} \\
\left(\mathrm{m}^{2} \mathrm{~g}^{-1}\right)\end{array}$ & $\begin{array}{l}\text { Average pore } \\
\text { diameter }(\mathrm{nm})\end{array}$ & $\begin{array}{l}\text { Total pore volume } \\
\left(\mathrm{cm}^{3} \mathrm{~g}^{-1}\right)\end{array}$ \\
\hline CG & 444 & 3.61 & 0.44 \\
CG-0.5GIC & 466 & 3.70 & 0.43 \\
CG-1.0GIC & 485 & 5.25 & 0.58 \\
CG-2.0GIC & 547 & 7.58 & 1.04 \\
\hline
\end{tabular}

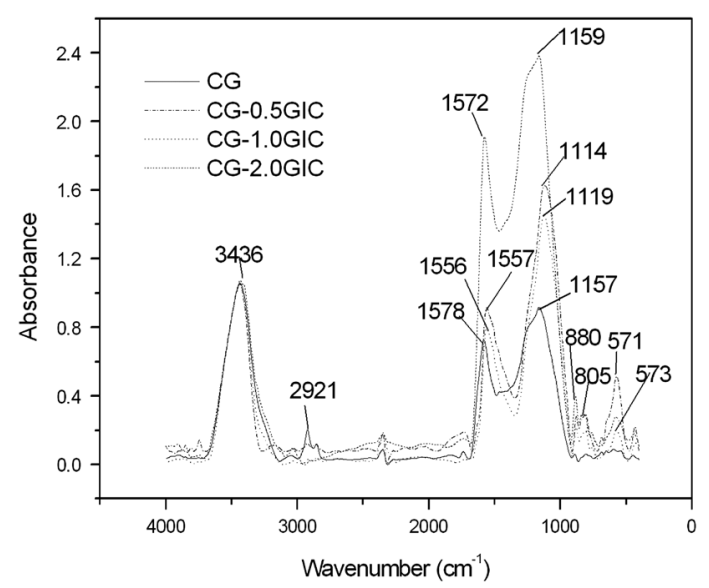

Fig. 5 FTIR spectra of CG and CG-GIC composites

\subsection{Effect of $\mathrm{pH}$}

Adsorption is a process which depends on many factors such as the physicochemical properties of the adsorbent, the concentration and the characteristics of the heavy metal ions, and the $\mathrm{pH}$ of the solution. The latter is an important parameter for the removal of heavy metal ions from aqueous solutions, because it affects the solubility of adsorbates, concentration of the counter ions on the functional groups of the adsorbent and the degree of ionisation of the adsorbate during reaction [44].

Removal of heavy metal ions was studied as a function of $\mathrm{pH}$ over a $\mathrm{pH}$ range of 3-7 on carbon gel and composites at the initial concentration of $50 \mathrm{mg} / \mathrm{l}$ as shown in Fig. 6. As can be seen from this figure the maximum adsorption was reached when the $\mathrm{pH}$ was 7 .

The increase in metal removal as the $\mathrm{pH}$ increases can be explained on the basis of a decrease in competition between proton and metal cations for the same functional groups and by the decrease in positive surface charge, which lowers electrostatic repulsion between the surface and the metal ions [16]. But the higher $\mathrm{pH}$ also caused the precipitation of metal hydroxides. The effect of $\mathrm{pH}$ on the precipitation of $\mathrm{Cu}(\mathrm{II}), \mathrm{Ni}(\mathrm{II}), \mathrm{Pb}(\mathrm{II})$ and $\mathrm{Co}(\mathrm{II})$ was studied over a $\mathrm{pH}$ range of 3-7 and is presented in Fig. 7. This figure shows that the removal of metal ions by precipitation started from $\mathrm{pH}>4$. From this moment partial hydrolysis took place, resulting in the formation of $\mathrm{MOH}^{+}$and $\mathrm{M}(\mathrm{OH})_{2}$. For this reason, in order to exclude overlaps of the adsorption with metal precipitation, studies of the adsorption on carbon gel and carbon composites were carried out at $\mathrm{pH} 3$.

\subsection{Effect of contact time and initial concentration of heavy metal}

The effect of contact time on the adsorption capacities of carbon gel and carbon composites for different initial metal ion concentrations is presented in Figs. 8-10. The equilibrium time is one of the most important parameters for a cost-effective wastewater treatment process.

From the curves presented in these figures, one can see that in all cases, metal ions' removal efficiency increased with longer contact time. Metal ions were adsorbed quite rapidly initially, however the adsorption capacity became slower with the passage of time. The initial faster rate of removal of each metal ion (Figs. 8-10) was may be due to the availability of the uncovered surface area of the carbon gel and composites, since adsorption kinetics depends on the surface area of the adsorbent.

It can be seen that for most of the studied systems, the contact time required for the adsorption of metal ions is relatively short and usually $3 \mathrm{~h}$ were needed to reach the equilibrium state (Figs. 8-10). Only a small increase in adsorption beyond this time is observed. However in a study conducted by Meena et al. [16] on commercial carbon aerogel (supplied by Marketech International, USA), found that the optimal contact time required to attain equilibrium was about $48 \mathrm{~h}$ but for $\mathrm{Mn}(\mathrm{II}), \mathrm{Zn}$ (II) and $\mathrm{Cu}(\mathrm{II})$, which was higher and was around $72 \mathrm{~h}$.

One can also see from the comparison of curves presented in Figs. 8-10 that although the adsorption capacity increased with increasing concentrations of metal ions, the extent of this rise was not proportional to the initial concentrations, eg a five-fold increase in the metal ion concentration did not lead to a five time higher adsorption capacity. An explanation of this can be in the availability of surface area of the carbon gel and composites on which the adsorption of metal ions occurred.

The effect of the initial concentration of metal ions on their removal from water solutions (at initial $\mathrm{pH}$ of 3 ) by the adsorption $(24 \mathrm{~h})$ on carbon gel and composites $(2 \mathrm{~g} / \mathrm{l})$ is presented in Fig. 11. One can observe that at $\mathrm{pH} 3$ and a contact time of $24 \mathrm{~h}$, the percent of metal removal is the highest, nearly 100 , for $\mathrm{Pb}(\mathrm{II})$ ions. For these ions, it is seen that percentage removal is almost complete $(99.22 \%)$ for the initial metal ions' concentration level $10 \mathrm{mg} / \mathrm{l}$ and for $2 \mathrm{~g} / \mathrm{l}$ adsorbent dose for all carbon gels (Fig. 11a). At the 

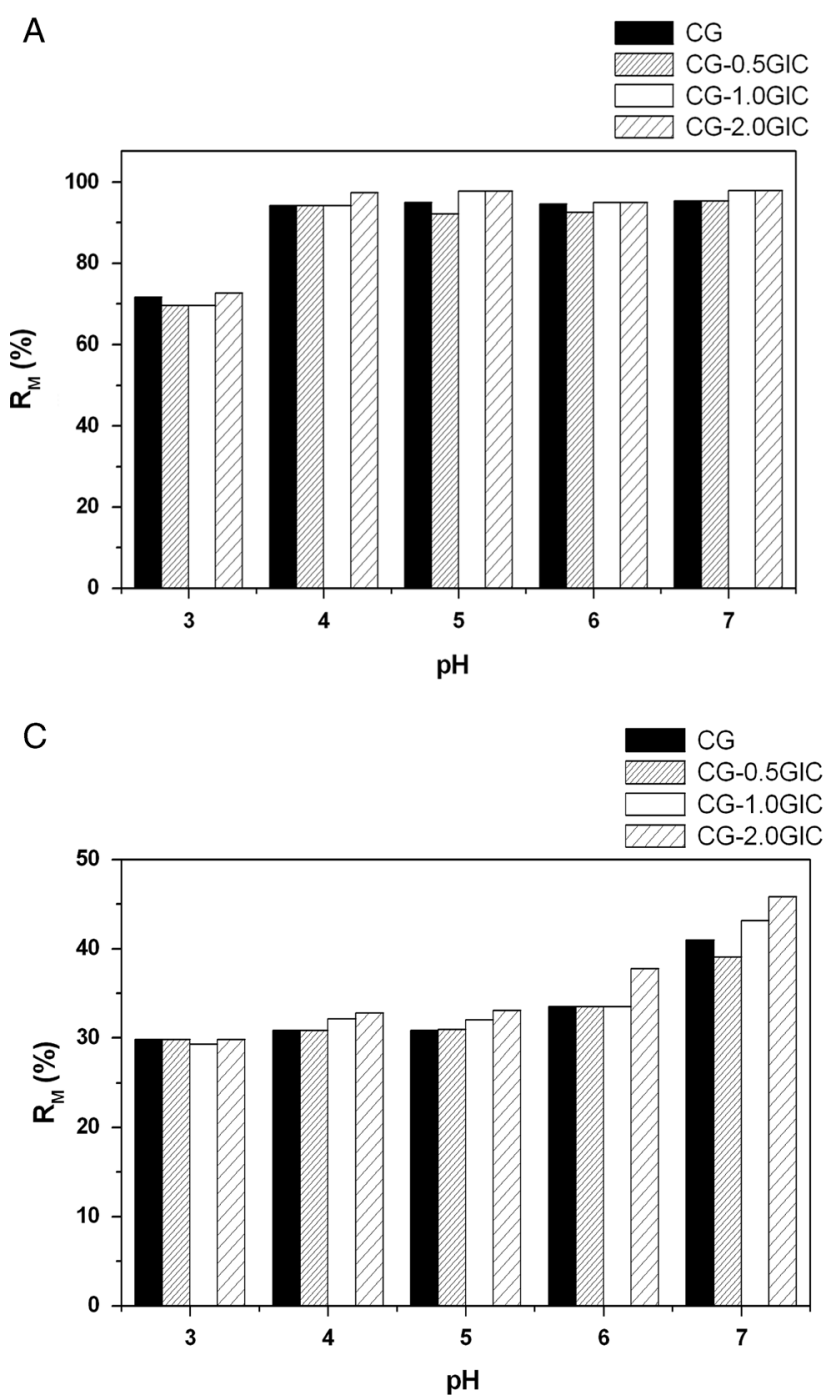

B

CG

CG-0.5GIC CG-1.0GIC

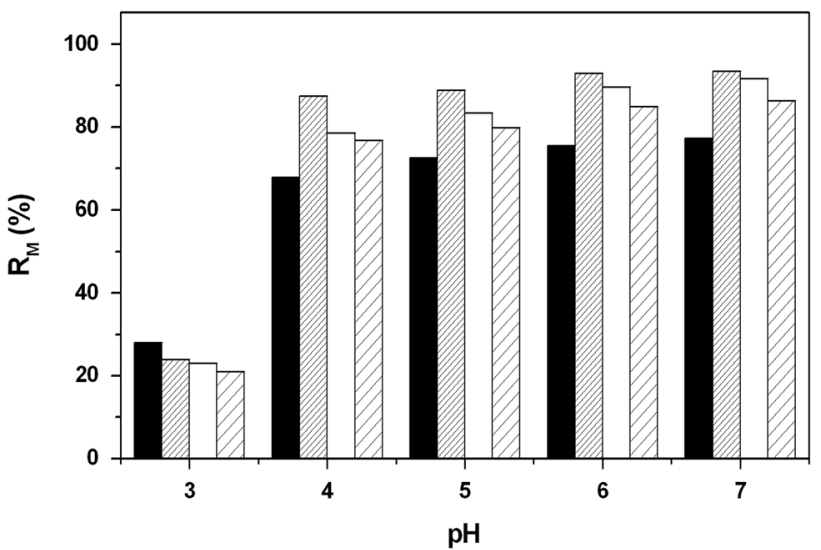

D CG CG-0.5GIC CG-1.0GIC ZIJ CG-2.0GIC

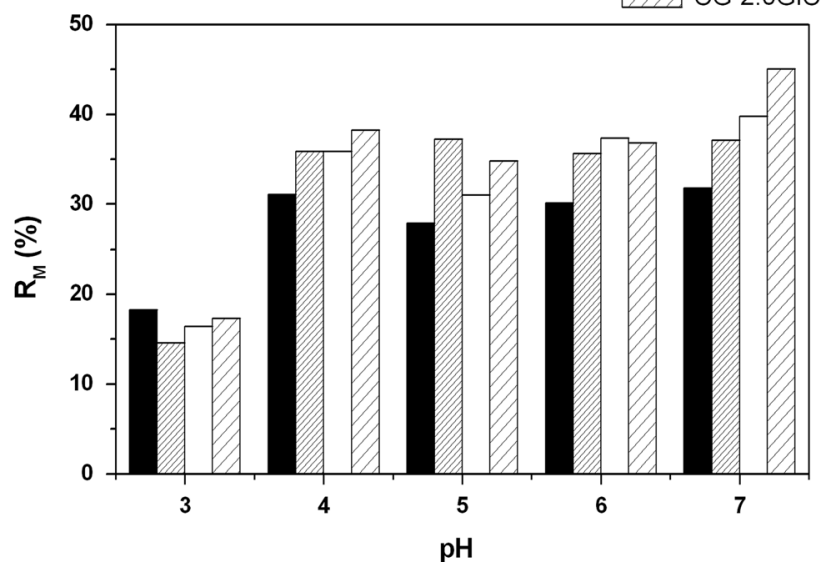

Fig. 6 Effect of $\mathrm{pH}$ on the removal of $\mathbf{a} \mathrm{Pb}, \mathbf{b} \mathrm{Cu}, \mathbf{c} \mathrm{Co}$ and $\mathbf{d} \mathrm{Ni}$ ions by $\mathrm{CG}$ and CG-GIC composites

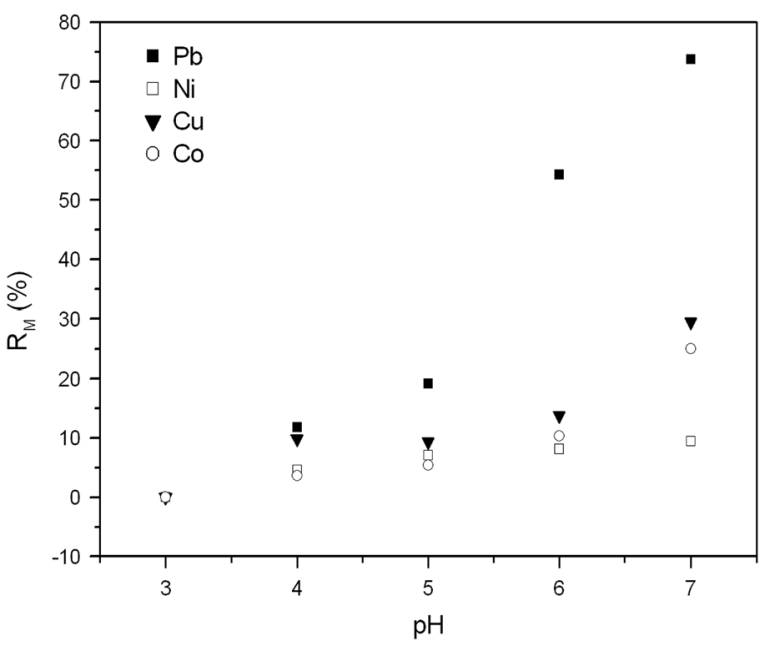

Fig. 7 Effect of $\mathrm{pH}$ on the precipitation of heavy metal ions higher initial concentration of metal ions of $25 \mathrm{mg} / \mathrm{l}$, there is a slight drop in percentage removal of $\mathrm{Pb}(\mathrm{II})$ for $\mathrm{CG}-2.0 \mathrm{GIC}$ $(98.92 \%)$. The same degree of removal of $\mathrm{Pb}$ ions was recorded for sample CG-1.0GIC. A lower efficiency yield of $85.43 \%$ for samples CG-0.5GIC and CG was achieved.

A further decline in efficiency was observed for all the samples of adsorbents for solutions with the concentration $50 \mathrm{mg} / \mathrm{l}$.

For $\mathrm{Cu}$ (II), $\mathrm{Co}$ (II) and $\mathrm{Ni}$ (II) (Fig. 11b, c) the similar relationship as for $\mathrm{Pb}$ (II) was noted but in the case of these metal ions a lower percentage removal than for $\mathrm{Pb}$ (II) was obtained. The efficiency of removal of these ions range from about $15 \%$ for solution of $50 \mathrm{mg} \mathrm{Ni(II)/l} \mathrm{on} \mathrm{CG} \mathrm{to} 84 \%$ for solution of $10 \mathrm{mg} \mathrm{Cu}$ (II)/l on CG-2.0GIC. The best adsorbent for $\mathrm{Cu}$ (II) was $\mathrm{CG}-2.0 \mathrm{GIC}$, for $\mathrm{Ni}$ (II) and $\mathrm{Co}$ (II) was CG2.0GIC and CG-1.0GIC (for both adsorbents the efficiency was $81,6 \%$ for Co and $68.93 \%$ for $\mathrm{Ni}$ ). 
Fig. 8 Effect of contact time on the adsorption capacities for a CG, b CG-0.5GIC, c CG1.0GIC and $\mathbf{d}$ CG-2.0GIC for an initial concentration of heavy metal ions of $10 \mathrm{mg} / \mathrm{l}$
Fig. 9 Effect of contact time on the adsorption capacities for a CG, b CG-0.5GIC, c CG$1.0 \mathrm{GIC}$ and $\mathbf{d} \mathrm{CG}-2.0 \mathrm{GIC}$ for an initial concentration of heavy metal ions of $25 \mathrm{mg} / \mathrm{l}$
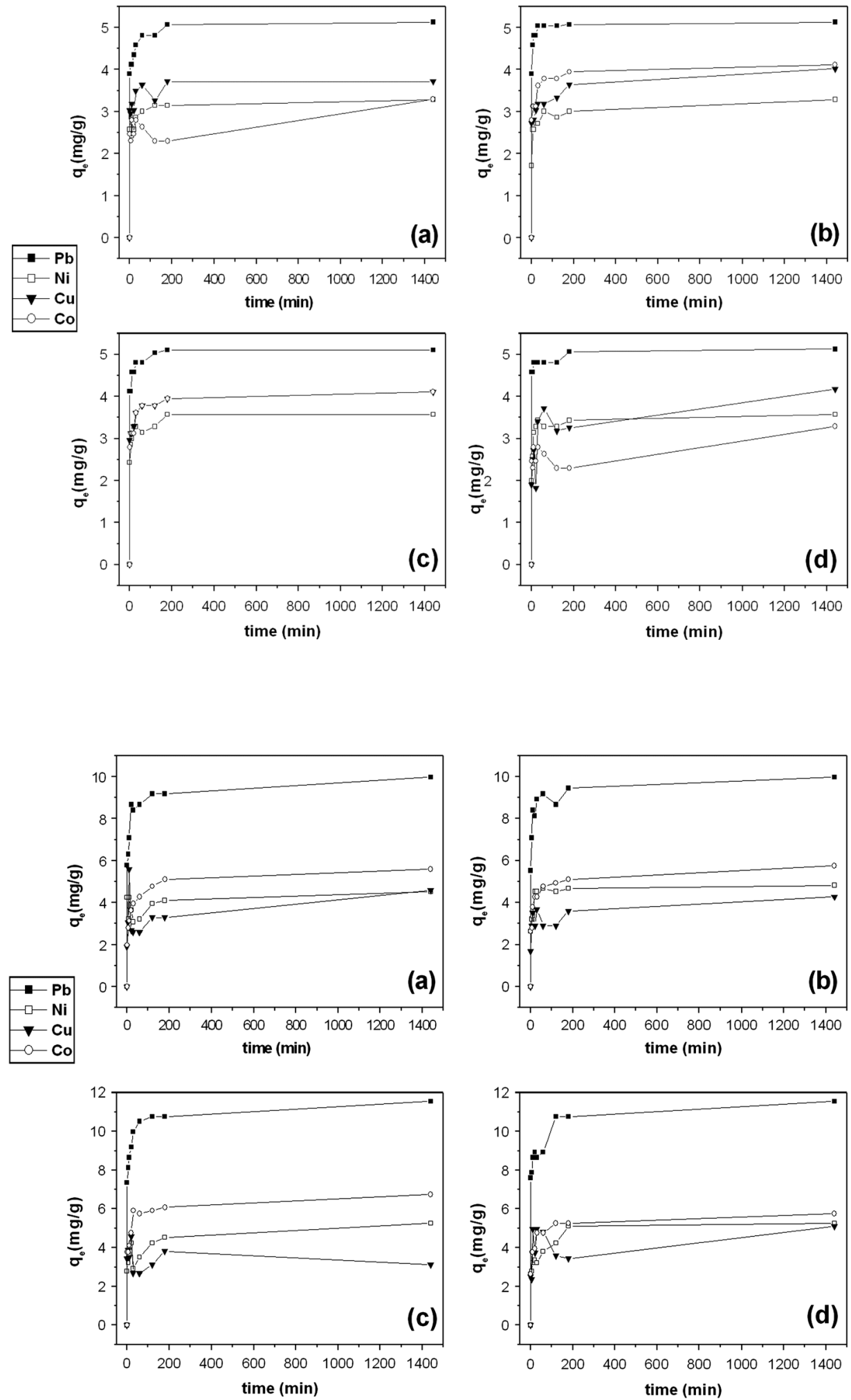

The results showed that the percentage removal increases with the decrease in the initial metal ions concentration. This can be explained because at lower initial concentrations, sufficient adsorption sites are available for adsorption of heavy metal ions. At higher concentrations, the numbers of heavy metal ions are relatively higher compared to the availability of adsorption sites [16]. Hence, the efficiency of removal of heavy metal ions depends on the initial 

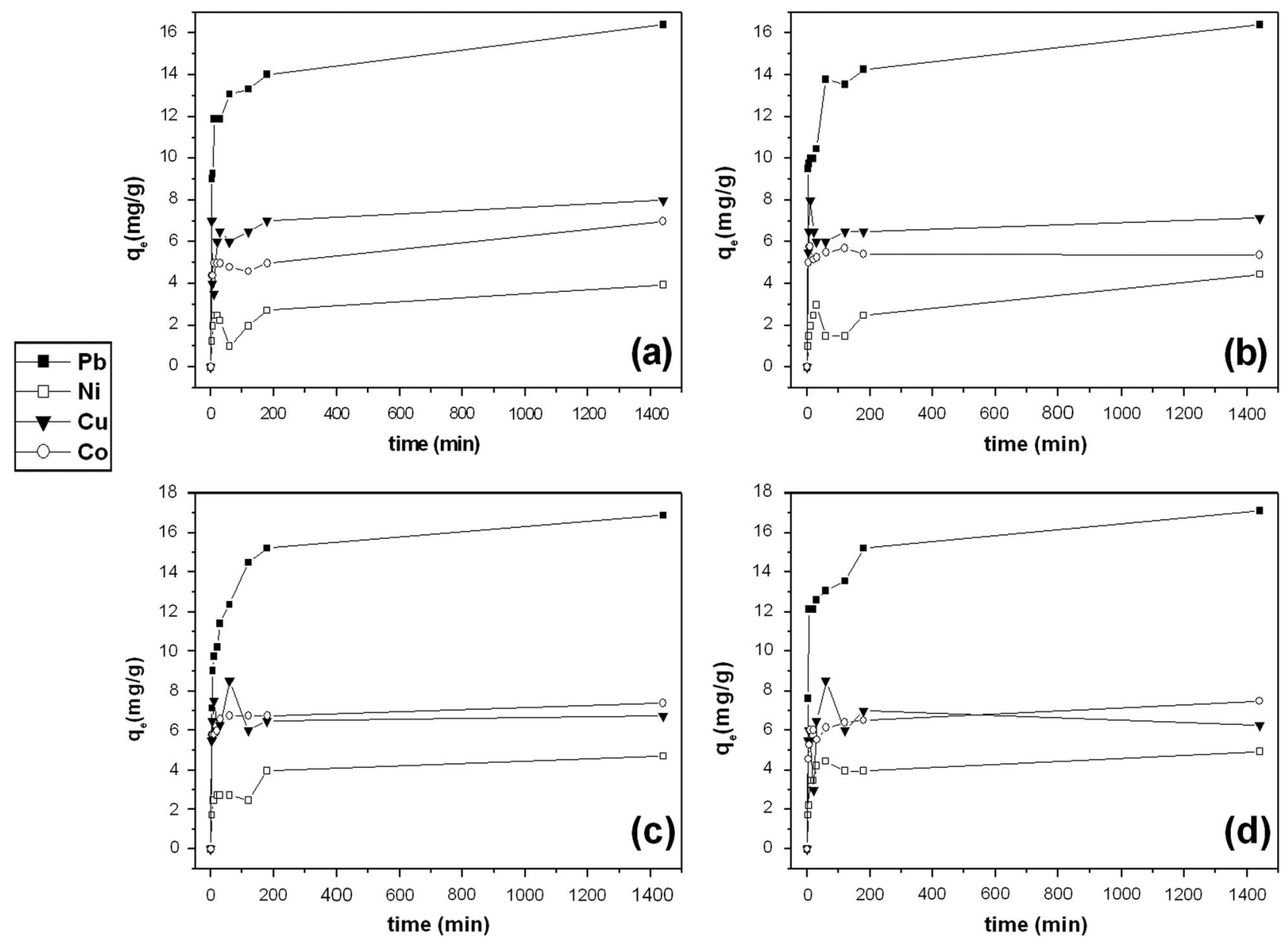

Fig. 10 Effect of contact time on the adsorption capacities for a CG, b CG-0.5GIC, $\mathbf{c}$ CG-1.0GIC and $\mathbf{d}$ CG-2.0GIC for an initial concentration of heavy metal ions of $50 \mathrm{mg} / \mathrm{l}$

concentration and increases as the initial metal ions concentration decreases.

Results also showed that for all initial metal ions concentrations $(50,25$ and $10 \mathrm{mg} / \mathrm{l})$, the final $\mathrm{pH}$ was higher than the initial $\mathrm{pH}$. The $\mathrm{pH}$ value changed, with a value which decreased when the initial metal ion concentration increased. The same relationship was observed by Goel and co-workers [17] and they concluded that as the initial metal ion concentrations increases, the resultant equilibrium $\mathrm{pH}$ decreases, as more metal ions are adsorbed onto carbon gel, more hydrogen ions are released, owing to dissociation of acidic surface functional groups in the carbon. These groups are considered responsible for the cation exchange capacity of carbon gel. This is in agreement with data obtained by FTIR measurements.

A particularly clear difference in the amount of removed metal ions, depending on their initial concentration, is seen for $\mathrm{Cu}(\mathrm{II})$. One can observe that the removal of $\mathrm{Cu}$ (II) was higher from the solution of the lowest concentration than from the solutions of higher concentrations. Removal of $\mathrm{Cu}$ (II) from the solutions of $10 \mathrm{mg} / \mathrm{l}$ changed from about 74 to $84 \%$ for CG and CG-2.0GIC, respectively, whereas it was about $50 \%$ lower for the solutions of $25 \mathrm{mg} / \mathrm{l}$. In this case, it can be assumed that the amount of acid groups involved in sorption was insufficient at higher concentrations of $\mathrm{Cu}$ (II). It was also found by Biniak et al. [32] that there was no relationship between the uptake of $\mathrm{Cu}$ (II) ions and the surface area of the carbons but the adsorption was strongly influenced by the presence of acidic functional groups on the carbon surface, and the $\mathrm{pH}$ of the solution.

\subsection{Adsorption isotherms}

To examine the relationship between sorbed $\left(q_{\mathrm{e}}\right)$ and aqueous concentrations of metal ions $\left(C_{\mathrm{e}}\right)$ at equilibrium (Fig. 12), Langmuir and Freundlich models were used. The Langmuir model assumes that the uptake of adsorbate molecules occurs on a homogenous surface by monolayer adsorption without any interaction between adsorbed molecules. Freundlich model is suitable for non-ideal adsorption on heterogeneous surfaces. The heterogeneity is caused by the presence of different functional groups on the surface, and various adsorbent-adsorbate interactions. To get the equilibrium data, initial metal ions' 

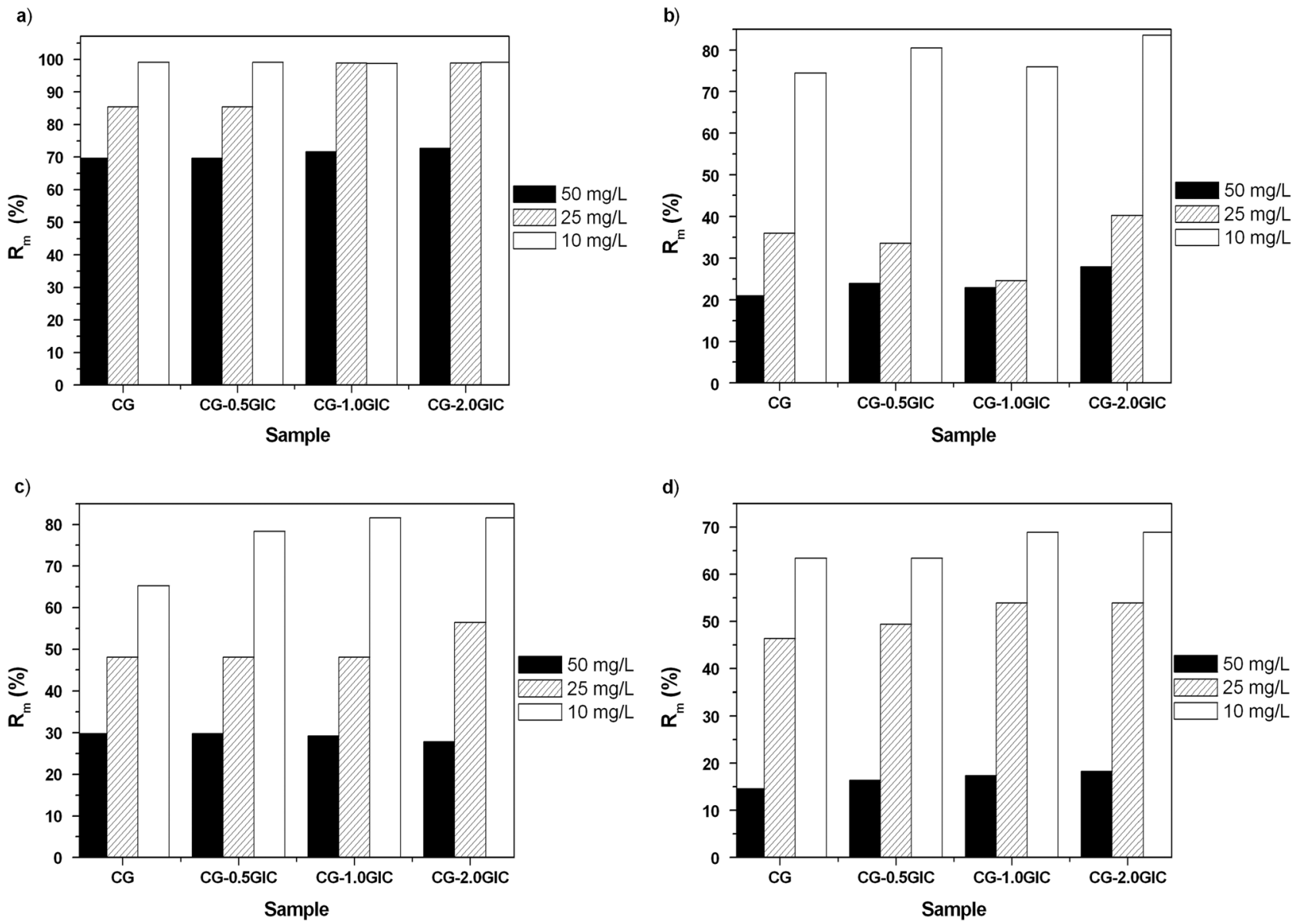

Fig. 11 Effect of initial concentration of $\mathbf{a} \mathrm{Pb}, \mathbf{b} \mathrm{Cu}, \mathbf{c} \mathrm{Co}$ and $\mathbf{d} \mathrm{Ni}$ ions on the removal, with $\mathrm{CG}$ and CG-GIC composites

concentrations were varied while the adsorbent masses were kept constant $(2 \mathrm{~g} / \mathrm{l})$ and the same equilibrium time $(24 \mathrm{~h})$ was used for sorption experiments on all samples.

Values of correlation coefficients and other parameters are given in Table 4.

The coefficients were calculated from the linear form of Langmuir equation:

$\frac{C_{\mathrm{e}}}{q_{\mathrm{e}}}=\frac{C_{\mathrm{e}}}{Q_{\mathrm{m}}}+\frac{1}{K_{\mathrm{L}} Q_{\mathrm{m}}}$

where $C_{\mathrm{e}}$ is the final concentration $(\mathrm{mg} / \mathrm{l}), q_{\mathrm{e}}$ is the amount of metal uptake at equilibrium $(\mathrm{mg} / \mathrm{g}), Q_{\mathrm{m}}$ is maximum adsorption capacity $(\mathrm{mg} / \mathrm{g}), K_{\mathrm{L}}$ is Langmuir adsorption constant $(1 / \mathrm{mg})$. Langmuir constants were calculated from the slopes and the intercept of plots of $C_{\mathrm{e}} / q_{\mathrm{e}}$ vs. $C_{\mathrm{e}}$.

The separation factor $R_{\mathrm{L}}$, an important parameter indicating the favorability of the adsorption based on the Langmuir equation, is defined by Weber and Chakravorti [45] as:

$R_{\mathrm{L}}=\frac{1}{\left(1+K_{\mathrm{L}} C_{\mathrm{i}}\right)}$ where $K_{\mathrm{L}}$ is the Langmuir constant and $C_{\mathrm{i}}$ is the highest initial metal concentration $(\mathrm{mg} / \mathrm{l})$.

The value of $R_{\mathrm{L}}$ indicates the type of adsorption either to be unfavourable $\left(R_{\mathrm{L}}>1\right)$, linear $\left(R_{\mathrm{L}}=1\right)$, favourable $(0<$ $\left.R_{\mathrm{L}}<1\right)$ or irreversible $\left(R_{\mathrm{L}}=0\right)[16,18,45]$.

The values of $R_{\mathrm{L}}$ for each of metal ions and adsorbents were between 0 and 1 , which indicates favourable adsorption.

The linear form of Freundlich isotherm was applied to the adsorption data of metal ions:

$\ln \left(q_{\mathrm{e}}\right)=\ln \left(K_{\mathrm{F}}\right)+\frac{1}{n_{\mathrm{F}}} \ln \left(C_{\mathrm{e}}\right)$

where $C_{\mathrm{e}}$ is the equilibrium concentration $(\mathrm{mg} / \mathrm{l}), q_{\mathrm{e}}$ is the amount of metal uptake at equilibrium $(\mathrm{mg} / \mathrm{g}), K_{\mathrm{F}}(\mathrm{l} / \mathrm{g})$ and $n_{\mathrm{F}}$ (dimensionless) are constants incorporating all factors affecting the adsorption capacity.

Straight lines were obtained by plotting $C_{\mathrm{e}} / q_{\mathrm{e}}$ against $C_{\mathrm{e}}$ as shown in Fig. 13, which indicated the applicability of Langmuirs adsorption isotherm. Consequently, the formation of monolayer coverage of the adsorbates on the surface of the adsorbent is suggested. The lines obtained by plotting $\ln q_{\mathrm{e}}$ against $\ln C_{\mathrm{e}}$ (as shown by Fig. 14) showed that the 
a)

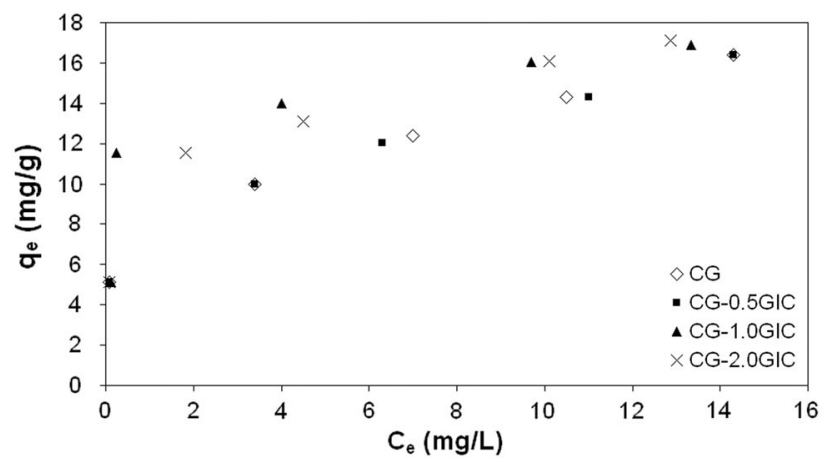

c)

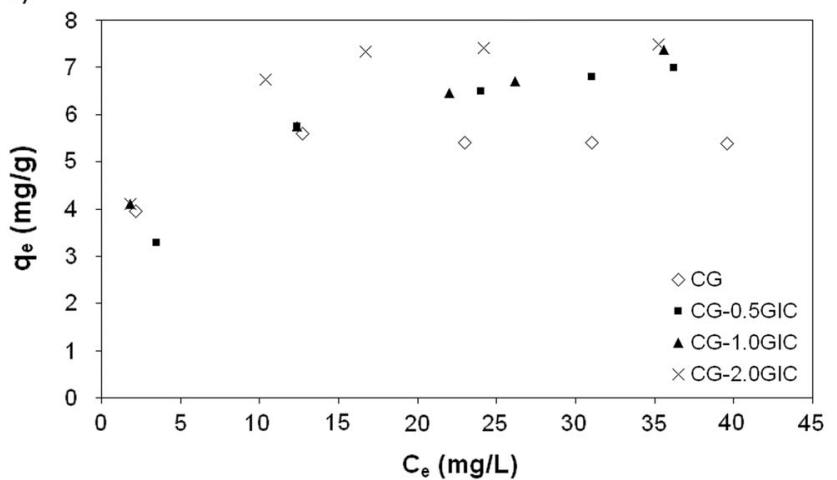

b)

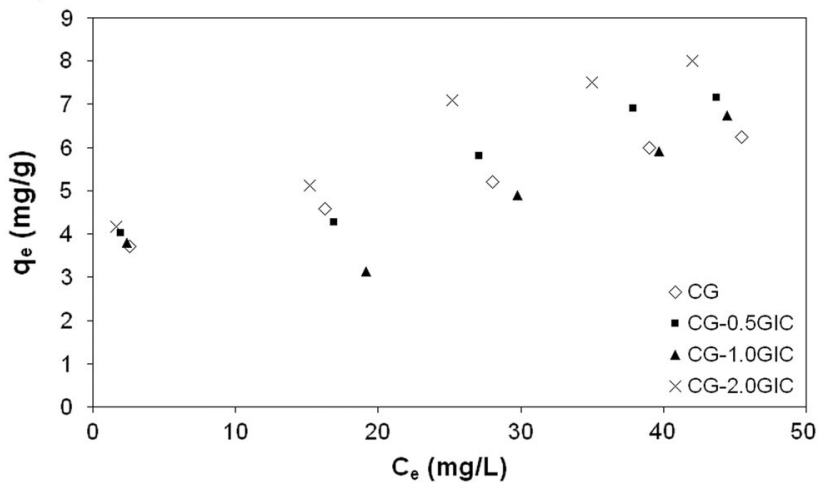

d)

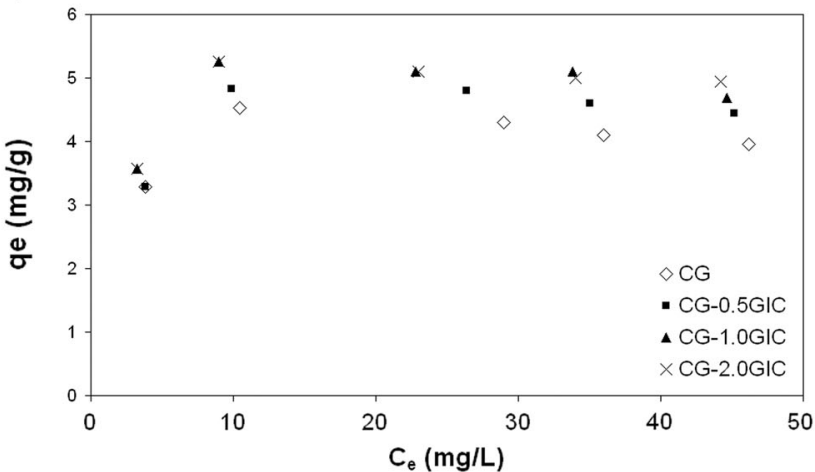

Fig. 12 Adsorption isotherms for $\mathbf{a} \mathrm{Pb}, \mathbf{b} \mathrm{Cu}, \mathbf{c} \mathrm{Co}$ and $\mathbf{d} \mathrm{Ni}$ ions onto $\mathrm{CG}$ and CG-GIC composites

Table 3 Acid-base properties of the adsorbents

\begin{tabular}{lllll}
\hline Sample & $\mathrm{pH}$ & $\begin{array}{l}\text { Acidic groups } \\
{[\mathrm{mmol} / \mathrm{g}]}\end{array}$ & $\begin{array}{l}\text { Basic groups } \\
{[\mathrm{mmol} / \mathrm{g}]}\end{array}$ & $\begin{array}{l}\text { Total content of surface oxides } \\
{[\mathrm{mmol} / \mathrm{g}]}\end{array}$ \\
\hline CG & 6.99 & 0.30 & 0.92 & 1.22 \\
CG-0.5GIC & 7.08 & 0.76 & 0.83 & 1.59 \\
CG-1.0GIC & 7.00 & 1.07 & 1.17 & 2.24 \\
CG-2.0GIC & 7.77 & 1.12 & 1.27 & 2.39 \\
\hline
\end{tabular}

adsorption of studied metal ions did not match the Freundlich isotherm very well. It is also evident from the correlation coefficient $\left(R^{2}\right)$ values that the Freundlich isotherm did not fit the experimental data well (Table 4).

It is clear from the Table 4 that the values of $Q_{\mathrm{m}}$ (monolayer adsorption capacity), as calculated from the Langmuir adsorption isotherms for metal ions was found to be the highest for $\mathrm{Pb}$ (II) and for composite CG-2.0GIC $(17.7 \mathrm{mg} / \mathrm{g})$ which was in agreement with the high surface area and high volume of pores. The adsorption capacity obtained for $\mathrm{Pb}$ (II) on composite $\mathrm{CG}-2.0 \mathrm{GIC}$ was much higher than that received by Meena et al. [16] $(0.75 \mathrm{mg} / \mathrm{g})$ for commercial carbon aerogel. The main reason for the higher capacity of composite CG-2.0GIC as compared to commercial carbon aerogel is its more than $28 \%$ higher
BET surface area. Also average pore diameter for composite CG-2.0GIC is much higher. Meena et al. [16] conducted their adsorption study at $\mathrm{pH}$ 6. It is known that at a $\mathrm{pH}$ less than 5, metal ions are mainly in the ionic form [46], higher $\mathrm{pH}$ results in the formation of hydrated ions. The structures of hydrated metal ions in aqueous solution display a variety of configurations depending on the size and electronic properties of the metal ion. The basic configurations of hydrated metal ions in aqueous solution are tetrahedral, octahedral, square antiprismatic, and tricapped trigonal prismatic [47]. The structure of the hydrated lead(II) ions is strongly affected by the lone electron pair, giving complexes with low symmetry (hemi-directed). The effectiveness of the adsorption process depends also on the size of ions in the aqueous phase; the hydrated radius of $\mathrm{Pb}(\mathrm{II})$ 
a)

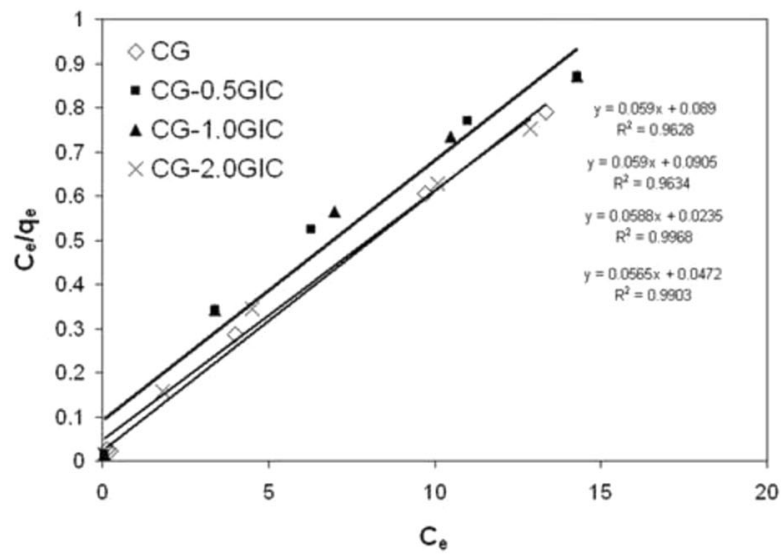

c)

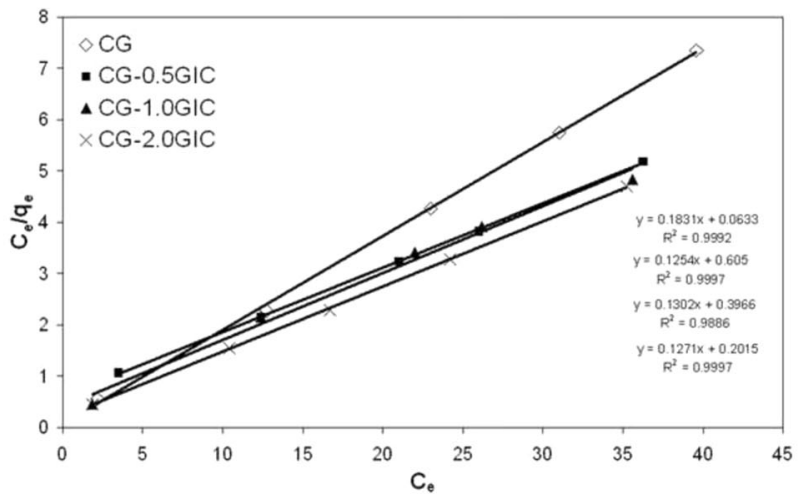

b)

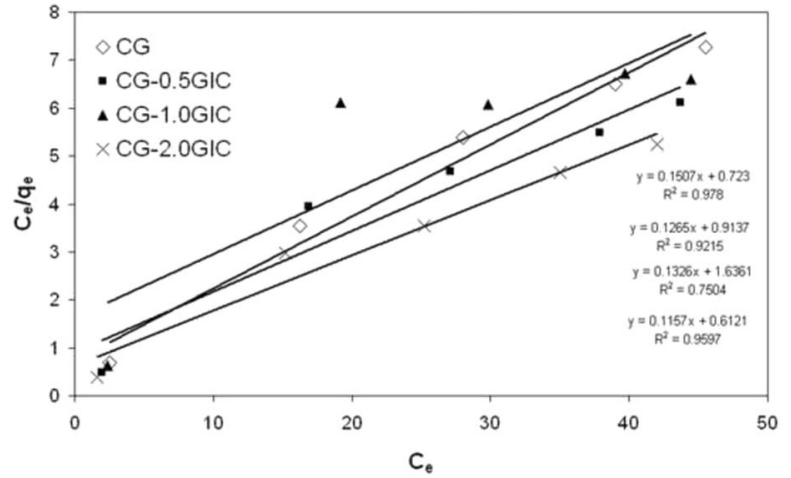

d)

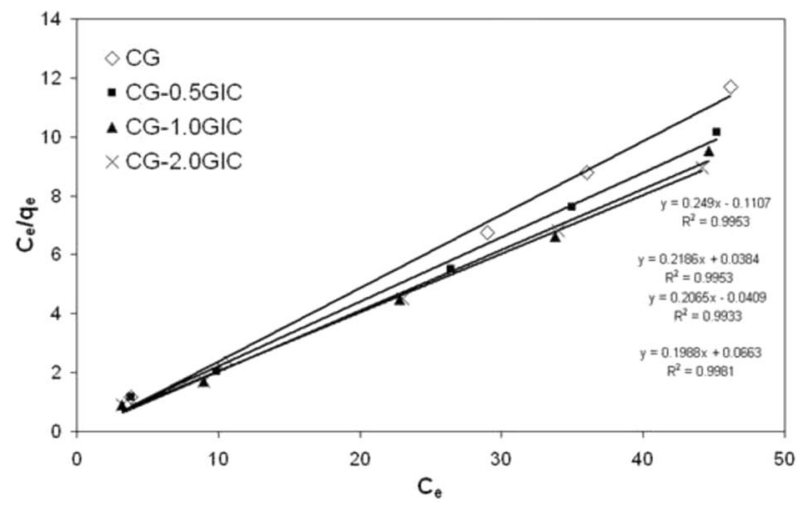

Fig. 13 Langmuir isotherm fit for adsorption onto carbon gel and composites for $\mathbf{a} \mathrm{Pb}, \mathbf{b ~ C u}, \mathbf{c} \mathrm{Co}$ and $\mathbf{d} \mathrm{Ni}$ ions

$(0.401 \mathrm{~nm})$ is higher as compared to the ionic radius of $\mathrm{Pb}$ (II) $(0.112 \mathrm{~nm})[18,46]$. Therefore $\mathrm{Pb}(\mathrm{II})$ ions have more accessibility to the surface and pores during the adsorption from the solutions at the lower $\mathrm{pH}$ of 3 than 6 , which in turn leads to the higher adsorption of lead (II) onto CG-2.0GIC. This is also consistent with the results obtained by Goel et al. [17] who conducted adsorption of metal ions from solutions at $\mathrm{pH}$ 4.5. Also Bohli et al. [42] noted that the important uptake of lead, even at low $\mathrm{pH}$, may be related to a higher affinity of the surface functional groups of carbons for this metal ions compared to the affinity towards copper and nickel.

There is no consensus between researches regarding the adsorption on metal ions. In comparison to other carbon gels studied for heavy metal ions adsorption, the adsorption order changes strongly from one adsorbent to another. Meena et al. [16] found that $\mathrm{Cd}(\mathrm{II})$ metal ion was much better adsorbed than $\mathrm{Pb}$ (II), but an opposing tendency was found for these metal ions by Kardivelu et al. [18]. The selectivity of adsorption was found by Meena [16] to decrease in the order: $\mathrm{Cd}>\mathrm{Cu}>\mathrm{Hg}>\mathrm{Ni}>\mathrm{Pb}$, whereas the adsorption capacities order, determined by Kardivelu et al. [18], follow the trend $\mathrm{Hg}>\mathrm{Pb}>\mathrm{Cd}$. Similar differences were also observed during absorption of heavy metals onto activated carbons by different authors [40-42, 48-50]. Some consider that metal ions go through adsorption sites easily when the ionic diameter becomes small [40, 41, 48, 50]. These authors explained the differences in the adsorption based on the ionic radius, the large ionic radius induces a quick saturation of adsorption sites, because of steric overcrowding on the surface. Some researches [42, 49] reported that the adsorption of metals having a large ionic radius was higher than for those with a smaller ionic radius.

It seems that the difference in adsorption affinity order and adsorption amount may be related not only to metal ions' properties but also to physical-chemical properties of the adsorbent (morphology, surface area, pores distribution, functional groups). The reason for this is that a substance which is a good adsorbent for one adsorbate may not be a good adsorbent for another.

The best adsorbent for all metals was CG-2.0GIC with the order $\mathrm{Pb}($ II) $>\mathrm{Cu}($ II) $>\mathrm{Co}$ (II) $>\mathrm{Ni}$ (II). The weak 
(a)

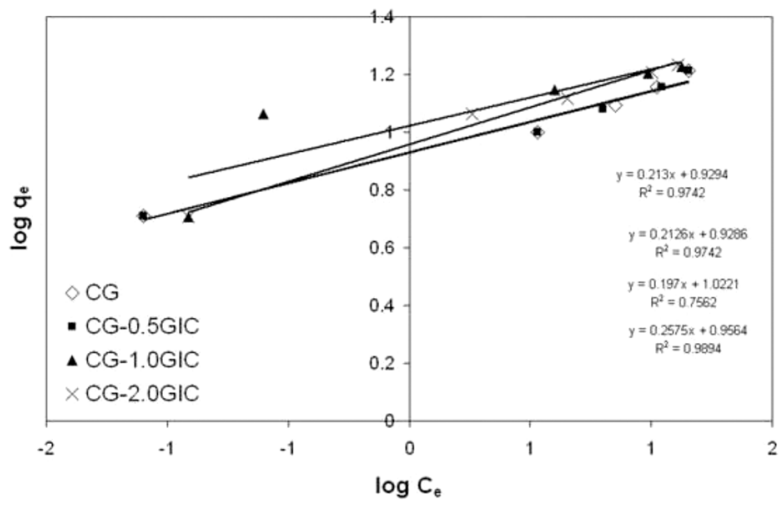

(c)

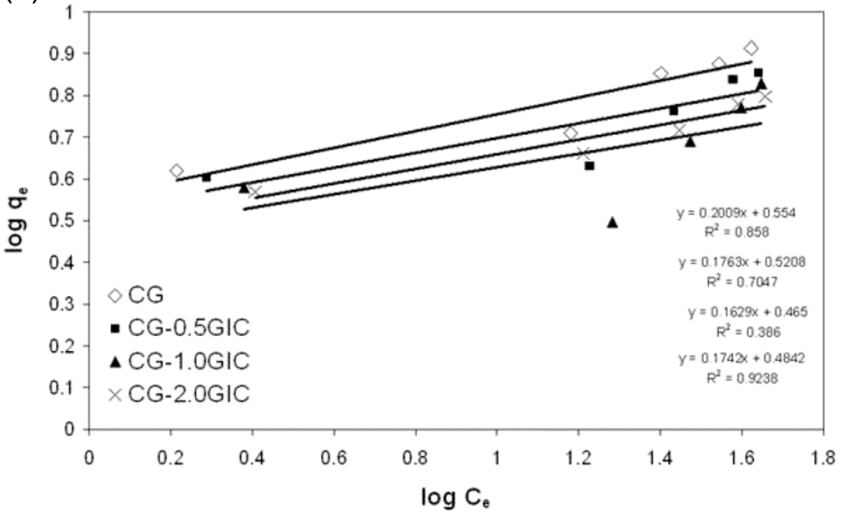

(b)

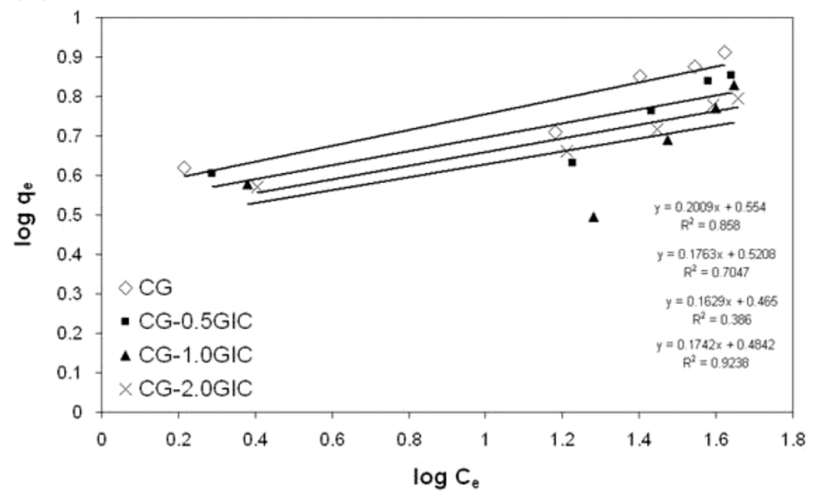

(d)

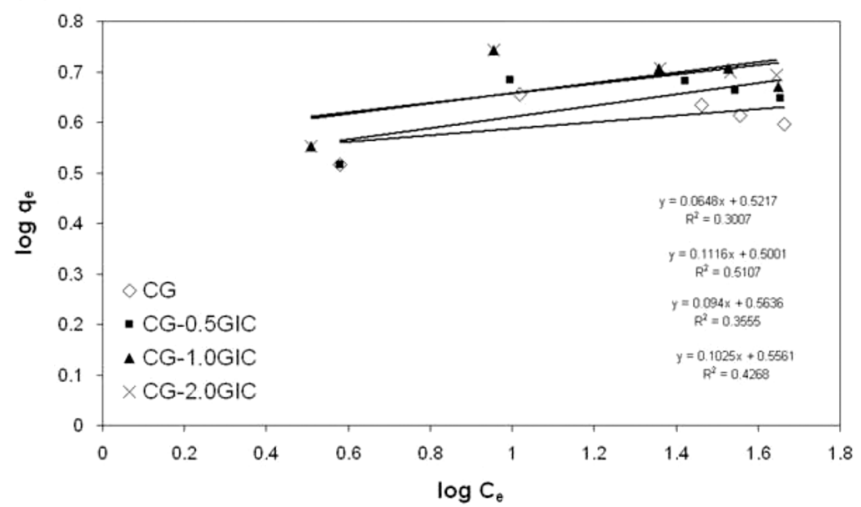

Fig. 14 Linerization according to Freundlich isotherms of $\mathbf{a ~} \mathrm{Pb}, \mathbf{b} \mathrm{Cu}, \mathbf{c} \mathrm{Co}$ and $\mathbf{d} \mathrm{Ni}$ ions adsorbet by carbon gel and composites

Table 4 Langmuir and Freundlich isotherm constants for heavy metal ions' adsorption on carbon gel and GIC containing carbon gels

\begin{tabular}{|c|c|c|c|c|c|c|c|c|}
\hline \multirow[t]{2}{*}{ Metal ion } & \multirow[t]{2}{*}{ Sample } & \multicolumn{4}{|c|}{ Langmuir parameters } & \multicolumn{3}{|c|}{ Freundlich parameters } \\
\hline & & $\overline{R^{2}}$ & $Q_{\mathrm{m}}[\mathrm{mg} / \mathrm{g}]$ & $K_{\mathrm{L}}[1 / \mathrm{mg}]$ & $R_{\mathrm{L}}$ & $\overline{R^{2}}$ & $n_{\mathrm{F}}$ & $K_{\mathrm{F}}[1 / \mathrm{g}]$ \\
\hline \multirow[t]{4}{*}{$\mathrm{Pb}$} & CG & 0.9628 & 16.95 & 0.6629 & 0.029 & 0.9742 & 4.6948 & 8.4946 \\
\hline & CG-0.5GEC & 0.9634 & 16.95 & 0.6519 & 0.030 & 0.9742 & 4.7037 & 8.4840 \\
\hline & CG-1.0GEC & 0.9968 & 17.01 & 2.5016 & 0.008 & 0.7562 & 5.0761 & 10.5220 \\
\hline & CG-2.0GEC & 0.9903 & 17.70 & 1.1976 & 0.016 & 0.9894 & 3.8835 & 8.9826 \\
\hline \multirow[t]{4}{*}{$\mathrm{Cu}$} & CG & 0.9780 & 6.64 & 0.2084 & 0.096 & 0.8580 & 4.9776 & 3.3810 \\
\hline & CG-0.5GEC & 0.9215 & 7.91 & 0.1384 & 0.144 & 0.7047 & 5.6721 & 3.3174 \\
\hline & CG-1.0GEC & 0.7504 & 7.54 & 0.0810 & 0.247 & 0.3860 & 6.1387 & 2.9174 \\
\hline & CG-2.0GEC & 0.9597 & 8.64 & 0.1890 & 0.106 & 0.9238 & 5.7405 & 3.0493 \\
\hline \multirow[t]{4}{*}{ Co } & $\mathrm{CG}$ & 0.9992 & 5.46 & 2.8927 & 0.007 & 0.9579 & 3.0950 & 2.2956 \\
\hline & CG-0.5GEC & 0.9997 & 7.97 & 0.2073 & 0.001 & 0.7929 & 1.0111 & 3.7776 \\
\hline & CG-1.0GEC & 0.9886 & 7.68 & 0.3283 & 0.057 & 0.9928 & 5.2301 & 3.6183 \\
\hline & CG-2.0GEC & 0.9997 & 7.86 & 1.5854 & 0.012 & 0.9315 & 4.6382 & 3.7644 \\
\hline \multirow[t]{4}{*}{$\mathrm{Ni}$} & CG & 0.9953 & 4.16 & 2.2493 & 0.009 & 0.3007 & 15.4321 & 3.3243 \\
\hline & CG-0.5GEC & 0.9953 & 4.57 & 5.6927 & 0.003 & 0.5107 & 8.9606 & 3.1630 \\
\hline & CG-1.0GEC & 0.9933 & 4.84 & 5.0490 & 0.004 & 0.3555 & 10.6383 & 3.6610 \\
\hline & CG-2.0GEC & 0.9981 & 5.03 & 2.9985 & 0.007 & 0.4268 & 3.7610 & 3.5983 \\
\hline
\end{tabular}

adsorption of $\mathrm{Ni}$ (II) was also noted by Goel et al. [17] for commercial carbon aerogel of Lawrence Livermore National Lab (USA). They explained that it is due to its specificity of adsorption or adherence with some functional group present on the surface of the adsorbent. The adsorption capacities of $\mathrm{Ni}$ (II) found by them at $\mathrm{pH} 4.5$ was 
about two times lower than this obtained for composite CG2.0GIC, despite the fact that the BET surface area for carbon aerogel studied by them was higher $\left(700 \mathrm{~m}^{2} \mathrm{~g}^{-1}\right)$ than the BET surface area of composite CG-2.0GIC. Also Fiol et al. [51], Faur-Brasquet et al. [48] and Bohli et al. [42] noted that different carbon adsorbents had a relatively low adsorption capacity for nickel ions.

The better adsorption properties of CG-GIC composites are based on the difference of the specific surface area, pore volume and average pore diameter. One can assume that during the carbonisation of dried samples of gels with the addition of GIC, the exfoliation could take place leading to the formation of porous graphite. In the results of this process, the amount of surface groups was also changed (Fig. 5, Table 3).

Composite CG-2.0CIG retain considerable oxygen content, which results in characteristic surface properties as this oxygen takes part in the formation of extensive functionalities imparting acidity/basicity, hydrophylity, surface ionisable groups and others. Such functionalities contribute to a great extent to the important adsorption characteristics of this carbon material. Many authors have reported that carboxylic groups on adsorbents can play an important role in the adsorption of metal ions-carbons with high carboxylic functions are very efficient for metal ions' removal [41, 43, 48, 52].

\section{Conclusions}

In this work, the carbon gel and carbon-GIC composites prepared by the sol-gel method were used for the removal of heavy metals from aqueous solutions. These materials exhibited surface areas from 444 to $547 \mathrm{~m}^{2} \mathrm{~g}^{-1}$, for carbon gel and composite CG-2.0GIC, respectively. The changes in the morphology of the materials caused by the addition of $\mathrm{NiCl}_{2}-\mathrm{FeCl}_{3}$-GIC were evaluated by SEM images. The investigation of surface groups carried out by FTIR showed that some surface groups (in the region 1559-1578 and $1114-1159 \mathrm{~cm}^{-1}$ ) were more intense for composites; it was especially visible for composite CG-2.0GIC.

The removal of $\mathrm{Pb}$ (II), $\mathrm{Cu}$ (II), $\mathrm{Co}$ (II) and $\mathrm{Ni}(\mathrm{II})$ was found to be dependent on their initial concentration. The percentage removal decreased as the initial concentration of metal ions increased. The Frendlich and Langmuir isotherm equations have been used to describe the equilibrium data and the data fitted the Langmuir isotherm better for all of the adsorbents. The best adsorbent for all metal ions was carbon gel doped with $2.0 \mathrm{wt} \%$ of GIC. The results show that for this composite, the adsorption capacities $\left(Q_{\mathrm{m}}\right)$ from the Langmuir isotherm models were found to be 17.7, 8.64, 7.86 and $5.03 \mathrm{mg} \mathrm{g}^{-1}$ at $\mathrm{pH} 3.0$ for $\mathrm{Pb}$ (II), $\mathrm{Cu}$ (II), $\mathrm{Co}$ (II) and $\mathrm{Ni}(\mathrm{II})$, respectively.
Acknowledgments This research was supported by the Grant No. 03/31/DSPB/0311

\section{Compliance with ethical standards}

Conflict of interest The authors declare that they have no competing interests.

Open Access This article is distributed under the terms of the Creative Commons Attribution 4.0 International License (http:// creativecommons.org/licenses/by/4.0/), which permits unrestricted use, distribution, and reproduction in any medium, provided you give appropriate credit to the original author(s) and the source, provide a link to the Creative Commons license, and indicate if changes were made.

\section{References}

1. Yang B, Yu C, Yu Q, Zhang X, Li Z, Lei L (2015) N-doped carbon xerogels as adsorbents for the removal of heavy metal ions from aqueous solution. RSC Adv 5:7182-7191

2. Skowroński JM, Osińska M (2009) Hydrogen electrosorption on the carbon-metal composite electrodes. Przem Chem 88 (4):385-388

3. Skowroński JM, Osińska M (2012) Effect of nickel catalyst on physicochemical properties of carbon xerogels as electrode materials for supercapacitor. Curr Appl Phys 12:911-918

4. Osińska M (2016) The effect of catalyst and heat treatment on the properties of carbon-metal composites. $\mathrm{J}$ Porous Mater 23:365-373

5. Pekala RW (1989) Organic aerogels from the polycondensation of resorcinol with formaldehyde. J Mater Sci 24:3221-3227

6. Pröbstle H, Wiener M, Fricke J (2003) Carbon aerogels for electrochemical double layer capacitors. J Porous Mater 10:213-222

7. Wu D, Fu R, Zhang S, Dresselhaus MS, Dresselhaus G (2004) Preparation of low-density carbon aerogels by ambient pressure drying. Carbon N Y 42:2033-2039

8. Kim SJ, Hwang SW, Hyun SH (2005) Preparation of carbon aerogel electrodes for supercapacitors and their electrochemical characteristics. J Mater Sci 40:725-731

9. Jung HH, Hwang SW, Hyun SH, Lee KH, Kim GT (2007) Capacitive deionization charactristics of nanostructured carbon aerogel electrodes synthesized via ambient drying. Desalination 216:377-385

10. Lee YJ, Jung JC, Yi J, Baeck SH, Yoon JR, Song IK (2010) Preparation of carbon aerogel in ambient conditions for electrical double-layer capacitor. Curr Appl Phys 10:682-686

11. Tamon H, Ishizaka H, Yamamoto T, Suzuki T (2000) Influence of freeze-drying conditions on the mesoporosity of organic gels as carbon precursors. Carbon N Y 38:1099-1105

12. Moreno AH, Arenillas A, Calvo EG, Bermúdez JM, Menéndez JA (2013) Carbonisation of resorcinol-formaldehyde organic xerogels: Effect of temperature, particle size and heating rate on the porosity of carbon xerogels. J Anal Appl Pyrolysis 100:111-116

13. Skowroński JM, Osińska M (2014) The influence of thermal treatment on the electrochemical properties of carbon-Ni-Pd composites. J Sol-Gel Sci Technol 71:109-117

14. Chandra S, Bag S, Bhar R, Pramanik P (2011) Effect of transition and non-transition metals during the synthesis of carbon xerogels. Microporous Mesoporous Mater 138:149-156

15. Fort CI, Cotet LC, Danciu V, Turdean GL, Popescu IC (2013) Iron doped carbon aerogel-new electrode material for electrocatalytic reduction of $\mathrm{H}_{2} \mathrm{O}_{2}$. Mater Chem Phys 138:893-898 
16. Meena AK, Mishra GK, Rai PK, Rajagopal C, Nagar PN (2005) Removal of heavy metal ions from aqueous solutions using carbon aerogels as an adsorbent. J Hazard Mater B 122:161-170

17. Goel J, Kadirvelu K, Rajagopal C, Garg VK (2005) Investigation of lead, mercury and nickel from aqueous solutions onto carbon aerogel. J Chem Technol Biotechnol 80:469-476

18. Kadirvelu K, Goel J, Rajagopal C (2008) Sorption of lead, mercury and cadmium ions in multi-component system using carbon aerogel as adsorbent. J Hazard Mater 153:502-507

19. Girigs BS, El-Sherif IY, Attia AA, Fathy NA (2012) Textural adsorption of carbon xerogel adsorbents for removal of $\mathrm{Cu}$ (II) ions from aqueous solution. J Non-Cryst Solids 358:741-747

20. Zhao M, Liu P (2009) Adsorption of methylene blue from aqueous solutions by modified expanded graphite powder. Desalination 249:331-336

21. Goshadrou A, Moheb A (2011) Continuous fixed bed adsorption of C.I. Acid Blue 92 by exfoliated graphite: An experimental and modeling study. Desalination 269:170-176

22. Tryba B, Przepiórski J, Morawski AW (2003) Influence of chemically prepared $\mathrm{H}_{2} \mathrm{SO}_{4}$-graphite intercalation compound (GIC) precursor on parameters of exfoliated graphite (EG) for oil sorption from water. Carbon N Y 41:2013-2016

23. Vieira F, Cisneros I, Rosa NG, Trindade GM, Mohallem NDS (2006) Influence of the natural flake graphite particle size on the textural characteristic of exfoliated graphite used for heavy oil sorption. Carbon N Y 44:2582-2592

24. Takeuchi K, Fujishige M, Kitazawa H, Akuzawa N, Medina JO, Morelos-Gomez A, Cruz-Silva R, Araki T, Hayashi T, Terrones M, Endo M (2015) Oil sorption by exfoliated graphite from dilute oil-water emulsion for practical applications in produced water treatments. J Water Process Eng 8:91-98

25. Lutfullin MA, Shornikova ON, Vasiliev AV, Pokholok KV, Osadchaya VA, Saidaminov MI, Sorokina NE, Avdeev VV (2014) Petroleum products and water sorption by expanded graphite enhanced with magnetic iron phases. Carbon $\mathrm{N}$ Y 66:417-425

26. Seredych M, Tamashausky AV, Bandosz TJ (2008) Surface features of exfoliated graphite/bentonite composites and their importance for ammonia adsorption. Carbon N Y 46:1241-1252

27. Toyoda M, Inagaki M (2003) Sorption and Recovery of Heavy Oils by Using Exfoliated Graphite. Spill Sci Technol Bull 8:467-474

28. Osińska M (2015) Modification of carbon-metal composites using high-energy ball milling. Microporous Mesoporous Mater 214:95-100

29. Boehm HP, Diehl E, Heck W, Sappok R (1964) Surface oxides of carbon. Angew Chem 3:669-677

30. Kaźmierczak J, Nowicki P, Pietrzak R (2013) Sorption properties of activated carbons obtained from corn cobs by chemical and physical activation. Adsorption 19:273-281

31. Świątkowski A, Pakuła M, Biniak S, Walczyk M (2004) Influence of surface chemistry of modified activated carbon on its electrochemical behaviour in the presence of lead(II) ions. Carbon N Y 42:3057-3069

32. Biniak S, Świątkowski A, Pakuła M (2000) Electrochemical studies of phenomena at active carbon-electrolyte solution interfaces. In: Radovic LR (ed) Chemistry and physics of carbon, dekker, Basel, New York, NY

33. Puizy AM, Poddubnaya OI, Martínez-Alonso A, Suárez-García F, Tascón JMD (2005) Surface chemistry of porous-containing carbons of lignocellulosic origin. Carbon N Y 43:2857-2868
34. Suárez-García F, Martínez-Alonso A, Tascón JMD (2002) A comparative study of the thermal decomposition of apple pulp in the absence and presence of phosphoric acid. Polym Degrad Stab 75:375-383

35. Trick KA, Saliba TE (1995) Mechanisms of the phyrolysis of phenolic resin in a carbon/phenolic composite. Carbon N Y 33:1509-1515

36. Severini F, Formaro L, Pegoraro M, Posca L (2002) Chemical modification of carbon fiber surfaces. Carbon N Y 40:735-741

37. Retzko I, Fredrich JF, Lippitz A, Unger WES (2001) Chemical analysis of plasma-polymerized films: The application of X-ray photoelectron spectroscopy (XPS), X-ray absorption spectroscopy (NEXAFS) and fourier transform infrared spectroscopy (FTIR). J Electron Spectrosc Relat Phenom 121:111-119

38. Zhang L, Liu H, Wang M, Chen L (2007) Structure and electrochemical properties of resorcinol-formaldehyde polymer-based carbon for electric double-layer capacitors. Carbon $\mathrm{N}$ Y 45:439-1445

39. Park SH, McClain S, Tian ZR, Suib SL, Karwacki C (1997) Surface and bulk measurements of metals deposited on activated carbon. Chem Mater 9:176-183

40. Ücer A, Uyaniak A, Ayün SF (2006) Adsorption of Cu(II), Cd(II), $\mathrm{Zn}(\mathrm{II}), \mathrm{Mn}(\mathrm{II})$ and $\mathrm{Fe}(\mathrm{III})$ ions by tannic acid immobilized activated carbon. Sep Purif Technol 47:113-118

41. Lo SF, Wang SY, Tsai MJ, Lin LD (2012) Adsoorpton capacity and removal efficiency of heavy metal ions by Moso and Ma bamboo activated carbons. Chem Eng Res Des 90:1397-1406

42. Bohli T, Villaescusa I, Ouederni A (2013) Comparative study of bivalent cationic metals adsorption $\mathrm{Pb}(\mathrm{II}), \mathrm{Cd}(\mathrm{II}), \mathrm{Ni}(\mathrm{II})$, and $\mathrm{Cu}$ (II) on olive stones chemically activated carbon. J Chem Eng Process Technol 4:158-164

43. Kardivelu K, Faur-Brasquet C, Le Cloirec P (2000) Removal of $\mathrm{Cu}(\mathrm{II}), \mathrm{Pb}(\mathrm{II})$ and $\mathrm{Ni}(\mathrm{II})$ by adsorption onto activated carbon cloths. Langmuir 16:8404-8409

44. Sharma A, Bhattacharyya KG (2004) Adsorption of chromium (VI) on Azadirachta indica (neem) leaf powder. Adsorption 10:327-338

45. Weber TW, Chakravorti RK (1974) Pore and solid diffusion models for fixed-bed adsorbers. J Am Inst Chem Eng 20:228-238

46. Faur-Brasquet C, Kardivelu K, Le Cloirec P (2002) Removal of metal ions from aqueous solution by absorption onto activated carbon cloth: adsorption competition with organic matter. Carbon N Y 40:2387-2392

47. Person I (2010) Hydrated metal ions in aqueous solution: how regular are their structures? Pure Appl Chem 82/10:1901-1917

48. Faur-Brasquet C, Kardivelu K, Le Cloirec P (2002) Modeling the adsorption of metal ions $\left(\mathrm{Cu}^{2+}, \mathrm{Ni}^{2+}, \mathrm{Pb}^{2+}\right)$ onto ACCs using surface complexion models. Appl Surf Sci 196:356-3665

49. Ricordel S, Taha S, Cisse I, Dorange G (2005) Heavy metals removal by adsorption onto peanut husks carbon: characterization, kinetic study and modeling. Sep Purif Technol 24:389-401

50. Gao Z, Bandosz TJ, Han M, Qiu J (2009) Investigation of factors affecting adsorption of transition metals on oxidized carbon nanotubes. J Hazard Mater 167:357-365

51. Fiol N, Villaescusa I, Martinez M, Miralles N, Poch J (2006) Sorption of $\mathrm{Pb}(\mathrm{II}), \mathrm{Ni}(\mathrm{II}), \mathrm{Cu}(\mathrm{II})$ and $\mathrm{Cd}(\mathrm{II})$ from aqueous solution by olive stone waste. Sep Purif Technol 50:132-140

52. Machida M, Yanazaki R, Aikawa M, Tatshumoto H (2005) Role of minerals in carbonaceous adsorbents for removal of $\mathrm{Pb}$ (II) ions from aqueous solution. Sep Purif Technol 46:88-94 